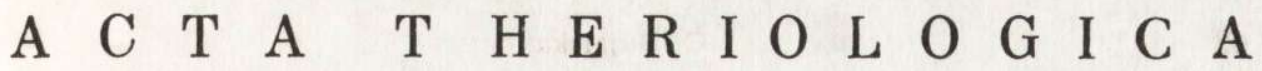

VOL. 20, 3: $41-56$.

April, 1975

Gabriela B U J A L S K A

\section{Reproduction and Mortality of Bank Voles and the Changes in the Size of an Island Population}

[With 2 Tables \& 2 Figs.]

\begin{abstract}
The present study was carried out on a four-hectare island in north-eastern Poland between 1966 and 1969. Each year, five trapping programmes were carried out using the CMR method; this assured that all the members of the population were caught. High survival of the spring generation has been shown to cause the occurrence of a peak in the size of the population. The survival of the young in the nest, which was correlated with the survival of the nursing females, was particularly important. There was no significant effect of the number of the newborn animals in the spring generation on the occurrence of the July peak in the size of the population. The survival of sexually immature females was found to be higher than that of mature females during breeding season, and an increase in the survival of the latter was observed after the breeding season. Of special importance was the lack of an inverse relationship between the population density and mortality and also the compensating action of reproduction and mortality in the regulation of the population size.
\end{abstract}

\section{INTRODUCTION}

In searching for mechanisms responsible for changes in the size of populations, investigators have traced mutual relations between the size, reproduction, mortality and migrations of a population. The results of studies on small rodents indicate that an increase in the size of population is accompanied by an increase in reproduction and a fall in mortality. The opposite occurs in the case of a decrease in the population, which is often accompanied by phenomena characteristic of stress (K a lela, 1957; Christian, 1961; Bergstedt, 1965; Kre b s, 1970).

A study on the changes in the size of an island population of bank voles Clethrionomys glareolus ( $\mathrm{S} \mathrm{ch} \mathrm{reber}, 1780$ ) has been carried out in Poland for several years. The exclusion of migration reduces con- 
siderations of the changes in the number of animals to an analysis of reproduction and mortality (G liw ic z et al., 1968). It has been demonstrated that the number of young born was constant $(\mathrm{B} \mathrm{u} \mathrm{jals} \mathrm{ka \text {, }}$ 1970 ) and this constancy was the result of regulatory processes (B uj a ls k a, 1973).

The stability of reproduction along with fluctuations in the size of the population points to a significant role of the mortality rate. An attempt has been made to describe the processes characterizing the changes in mortality in both dense and sparse populations.

\section{AREA, MATERIAL AND METHODS}

The material was collected on a four-hectare island inhabited by a population of C. glareolus, between 1966 and 1969. The island is covered by a mixed forest. A list of phytosociological associations and the characteristics of the region are given in a paper by $\mathrm{Traczyk}$ (1965).

Five trapping programmes were carried out at six intervals from April to the end of October or the beginning of November in each year of the study. The rodents were caught by the CMR method in live traps with bait. During each series, all the members of the population were captured (Gliwicz et al., 1968). The size of the population was determined by the census method. Vaginal smears were analysed to distinguish pregnant and non-pregnant females $(\mathrm{B} \mathrm{ujalska}$ \& Ryszkowski, 1966; Bujalska et al., 1968; Bujalska, 1970). More detailed descriptions of the method of trapping have been given by Gliwicz et al. (1968) and B u ja l s k a (1970).

In each trapping programme, starting from June, young animals born earlier in the breeding season were captured; the young caught for the first time in June are referred to as cohort $K_{1}$, in July as cohort $K_{2}$, in September as cohort $K_{3}$ and in October or at the beginning of November as cohort $K_{4}$ (Gliwicz et al., 1968). The mean day of the birth of the young belonging to a given cohort was calculated on the basis of the changes in the number of pregnant females. It is the day on which half the specimens of this cohort were born. The number of newborn animals $v$ was estimated by the formula $v_{r}=\frac{\bar{N}_{p} T L}{t_{p}}$ (B u ja ls k a, 1967; $\mathrm{Bujalska}$ et al., 1968), where $\nu_{r}$ is the number of nowborn animals, $\bar{N}_{p}$ the mean number of pregnant females, $T$ the time of observation, in days, $L$ the size of litter (after $\mathrm{Zejda}, 1966$ ) and $t_{p}$ the duration of pregnancy (22 days, $\mathrm{Bu}$ jalska \& Ryszkowski, 1968).

\section{REPRODUCTION, SURVIVAL AND CHANGES IN THE SIZE OF THE POPULATION}

3.1. A Comparison of the Effect of Reproduction and that of Survival on the Formation of a Peak in the Population Size

An earlier study (Petrusewicz et al., 1971) shows that in 1966 and 1968 the largest size of the same island population of C. glareolus occurred in July, no peak being observed in this population in 1967 (Table 1). In June 1969 an experiment was carried out during which 
44 per cent of the members of cohort $K_{2}$ were removed from the

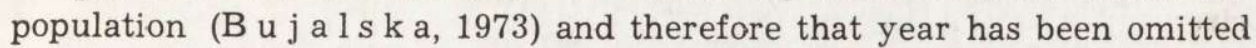
in the present considerations. In July the population size was characterized by the widest range of variation, from 2.4 to 1 (in September: $2.2-1$ ), and on the basis of the July data years with or without a peak in the population size have been distinguished. In this paper, an attempt has been made to find if the variation in the population size in July resulted from changes in the intensity of reproduction or from mortality.

It has been found that between 1966 and 1969 the annual reproduction of the population studied, expressed by the number of newborn animals, was constant, varying from 1011 specimens in 1968 to 1090 in 1967 (B u ja lska, 1970, 1973). Nevertheless, the numbers of animals born in the first and the second half of the breeding season were inversely proportional to each other $(\mathrm{Bujalska}, 1970)$. It may therefore be supposed that a peak in the size of the population occurs in the years characterized by a greater number of young born in the period from the outset of the breeding season until July.

Table 1

Changes in population numbers

\begin{tabular}{cccccc}
\hline Year & $\begin{array}{c}\text { End of } \\
\text { April }\end{array}$ & $\begin{array}{c}\text { Mid of } \\
\text { June }\end{array}$ & $\begin{array}{c}\text { End of } \\
\text { July }\end{array}$ & $\begin{array}{c}\text { Mid of } \\
\text { September }\end{array}$ & $\begin{array}{c}\text { End of } \\
\text { October }\end{array}$ \\
\hline 1966 & 56 & 152 & 304 & 262 & 166 \\
1967 & 68 & 160 & 167 & 177 & 201 \\
1968 & 70 & 339 & 399 & 389 & 230 \\
1969 & 62 & 96 & 157 & 182 & 145 \\
\hline
\end{tabular}

The following elements contribute to the size of the population in July: (1) the number of overwintering individuals, (2) the size of cohort $K_{1}$ (the number of newborn, the number of them which lived until their first capture, and the number of animals that survived the period from the June census until the July series of catches) and (3) the size of cohort $K_{2}$ (the number of newborn and the number of those living until their first capture). Of these parameters, only the number of newborn animals of cohorts $K_{1}$ and $K_{2}$ (they are termed the spring generation, whereas cohorts $K_{3}$ and $K_{4}$ form the autumn generation) and their survival until the first capture are worthy of special attention, since the number of overwintering animals is small in July (ranging from 12 in 1967 to 20 in 1968) and cannot have a major effect on the population size. In 1966-1968 the survival of individuals of cohort $K_{1}$ varied within a narrow range in the period from the first capture until July (70.2 per cent in 1966 to 81.3 per cent in 1968) and therefore it 
could not play a decisive role in producing a peak in the population size.

The size of the population in July was examined for its dependence on the number of newborn animals of the spring generation. For this purpose two sequences of empirical numbers, the number of newborn of the spring generation and the corresponding population size in July, were compared by the chi-squared test. The differences between the sequences were significant $(0.01<p<0.001)$, which indicates the lack of conformity between the sequences compared. Consequently, the number of newborn individuals of the spring generation did not determine the size of the population in July.

The question as to whether the survival of the spring generation in the period from the birth of the young until their first capture had played an important role with regard to the occurrence of a peak of the population was therefore analysed. The percentage of survivors from the spring generation and the population size in July were compared using the chi-squared test; it was shown that the differences between the sequences were not statistically significant. This indicates that the main factor influencing the peak size of a population is the survival of the young.

If it can be assumed, in accordance with the observations made by $\mathrm{Krebs}$, Keller \& T a marin (1969), that the general population processes in Microtus and Clethrionomys are similar, the foregoing may be expected to be a phenomenon typical of closed populations, for in open populations, the mortality of adult and subadult animals is of greater importance to the changes in population density.

\subsection{Survival and Mean Population Size}

The results presented above point to an actual relationship between the survival of the members of the spring generation and the occurrence of a peak in the population size in July. It therefore seems expedient to study the changes in the survival rate for all individuals in the period from their birth until the first capture and in the other periods of life, in years with large and small population sizes. As the number of animals born in each year was constant and the number of survivors in the next year nearly constant ( $\mathrm{Petr}$ us ew i c z et al., 1971), it is obvious that the same number of animals died each year $(980,1020,949$ and 1026 successively in 1966-1969 1). It was essential to determine which age groups showed a lower mortality in the year with a large population

\footnotetext{
1 The animals removed in 1969 are counted as having died.
} 
size. The results given in Section 3.1. indicate that this was the age group from birth to the first capture.

The distribution of mortality between the remaining, trappable groups composed of animals born in successive years were analysed. Three categories of animals were distinguished, of which only the first constitued a homogeneous age group: (1) from birth until the first capture,

(2) from the first capture until the last autumn trapping programme, and

(3) in winter (up to the first trapping programme in the spring of the

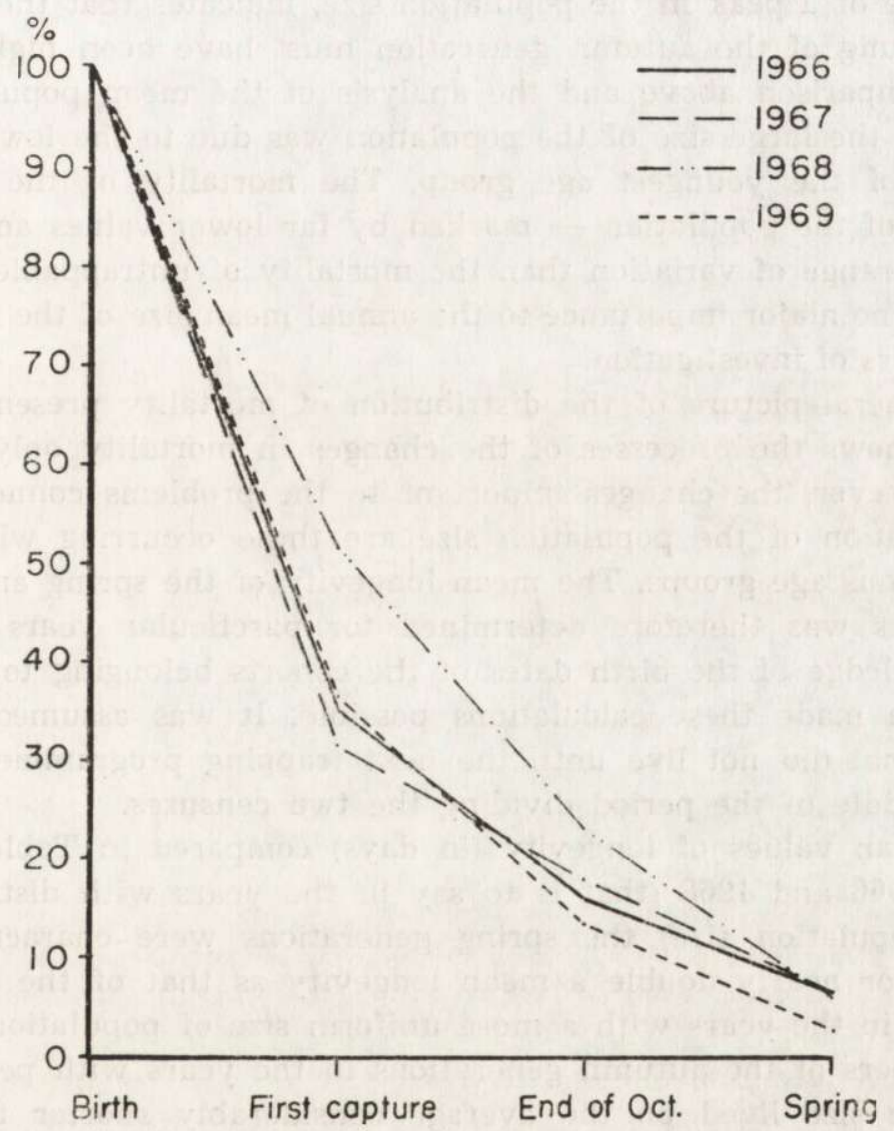

Fig. 1. Percentage of voles surviving until a defined time.

next year). The year of 1968 , which was marked by the largest mean size of population (285 individuals against 188, 155 and 128 in 1966, 1967 and 1969 respectively), was also characterized by the highest survival (percentage of survivors) of the young of the group from birth until the first capture (Fig. 1). On the other hand, the proportion of bank vole born in 1968 and surviving the summer - autumn period was 
the lowest. Also a low percentage of animals survived the winter (although it was somewhat higher than the percentage of survivors in 1969, but this last year should be regarded as exceptional, because the number of animals that lived until the spring of 1970 was smaller than usual, 24 as against 68,70 , and 62 , successively, in the preceeding years). The relatively low percentage of the youngest animals surviving in 1966, characterized by a high average population density, along with the high correlation between the survival of the young of the spring generation and the occurrence of a peak in the population size, indicates that the mortality of the young of the autumn generation must have been high.

The comparison above and the analysis of the mean population size show that the large size of the population was due to the low mortality of voles of the youngest age group. The mortality of the trappable members of the population - marked by far lower values and a much narrower range of variation than the mortality of untrappable juveniles - was of no major importance to the annual mean size of the population in the years of investigation.

The general picture of the distribution of mortality presented above (Fig. 1) shows the processes of the changes in mortality only over the year. However, the changes important to the problems connected with the regulation of the population size are those occurring within more homogeneous age groups. The mean longevity of the spring and autumn generations was therefore determined for parcticular years of study. The knowledge of the birth dates of the cohorts belonging to the given generation made these calculations possible. It was assumed that the animals that did not live until the next trapping programme had died in the middle of the period dividing the two censuses.

The mean values of longevity (in days) compared in Table 2 reveal that in 1966 and 1968 (that is to say in the years with distinct peaks in the population size) the spring generations were characterized by a double or nearly double a mean longevity as that of the spring generations in the years with a more uniform size of population, whereas the members of the autumn generations in the years with peaks in the population size lived on the average considerably shorter than those in the other years. It has also been found that in 1968 , which year was characterized by the highest mean size of population, the members of the autumn generation lived on the average longer than did these of the same generation in 1966 (respectively, 53 and 34 days), when, after its peak in July, the number of animals in the population had fallen rapidly. Generally speaking, big differences in survival between the two generations were observed in the years with a large size of population, whereas in the years with smaller fluctuations in the population 
size the survival rates of the generations were similar. This was reflected by the mean longevity of all the animals born in the years with large and small populations: the higher the values attained by the mean longevity of animals born in a given year, the higher was the mean population size. Thus it may be assumed that in the years of study a higher size of population was brought about by an increase in the longevity of specimens born in the given year.

The mean value of longevity of males and females belonging to the spring and autumn generations did not differ greatly (Table 2). However, there was a perceptible tendency (statistically non-significant differences) towards an increase in the mean longevity of females in the period preceeding the peak size of population. Nevertheless, this was not as

Table 2

Mean life-span and its standard deviation (in days).

\begin{tabular}{|c|c|c|c|c|}
\hline Year & Sex & Spring generation & $\begin{array}{l}\text { Autumn generation } \\
K_{3} K_{4}\end{array}$ & $\begin{array}{l}\text { Mean value for } \\
\text { generations }\end{array}$ \\
\hline 1966 & $\begin{array}{l}\text { Males } \\
\text { Females } \\
\text { Males \& Females }\end{array}$ & $\begin{array}{l}110 \pm 6.1 \\
122 \pm 7.3 \\
116 \pm 4.6\end{array}$ & $\begin{array}{l}33 \pm 2.2 \\
35 \pm 2.3 \\
34 \pm 1.6\end{array}$ & $\begin{array}{l}76 \pm 3.4 \\
84 \pm 3.6 \\
80 \pm 2.6\end{array}$ \\
\hline 1967 & $\begin{array}{l}\text { Males } \\
\text { Females } \\
\text { Males \& Females }\end{array}$ & $\begin{array}{l}78 \pm 4.4 \\
66 \pm 3.9 \\
72 \pm 2.9\end{array}$ & $\begin{array}{l}73 \pm 4.6 \\
70 \pm 4.6 \\
72 \pm 3.2\end{array}$ & $\begin{array}{l}76 \pm 3.3 \\
68 \pm 2.9 \\
72 \pm 2.2\end{array}$ \\
\hline 1968 & $\begin{array}{l}\text { Males } \\
\text { Females } \\
\text { Males \& Females }\end{array}$ & $\begin{array}{l}124 \pm 6.7 \\
132 \pm 7.6 \\
128 \pm 4.7\end{array}$ & $\begin{array}{l}45 \pm 3.6 \\
61 \pm 5.1 \\
53 \pm 3.0\end{array}$ & $\begin{array}{l}100 \pm 4.4 \\
110 \pm 5.0 \\
105 \pm 3.5\end{array}$ \\
\hline 1969 & $\begin{array}{l}\text { Males } \\
\text { Females } \\
\text { Males \& Females }\end{array}$ & $\begin{array}{l}60 \pm 3.5 \\
58 \pm 3.5 \\
59 \pm 2.5\end{array}$ & $\begin{array}{l}64 \pm 4.0 \\
55 \pm 4.0 \\
60 \pm 2.9\end{array}$ & $\begin{array}{l}62 \pm 2.7 \\
57 \pm 2.6 \\
60 \pm 1.8\end{array}$ \\
\hline
\end{tabular}

distinct a phenomenon as that described by $\mathrm{K} \mathrm{rebs}$ et ai. (1969) in Microtus ochrogaster.

On the other hand, it is noteworthy that the mean longevity of females of the autumn generation of 1968 was higher than that of males. This is interesting inasmuch as in 1966, in which year there also occurred a peak in the population size, the mean values of longevity of the males and females of the autumn generation were similar.

The analysis of the mean longevity of all the voles born in a given year indicates that in the years with a peak in the population size, females live longer than males (statistically significant differences) and in the years without such a peak they live shorter (1967) or show a tendency to a decrease in the mean longevity (1969). 


\section{SURVIVAL OF FEMALES AND THEIR REPRODUCTIVE CONDITION}

\subsection{Survival of Sexually Mature and Immature Females}

The mean longevity of females in the periods of life distinguished was examined for changes. As in the case of the analysis of survival of all animals in the first year of life, the following periods were distinguished in the life of the females:

1. The period from birth to the first capture, i.e. the first 44 days of life. Survival in this period was calculated on the basis of the estimated number of females born and the date of their birth, and expressed as percentage of the total number of females born. The sex ratio at birth was assumed to be $1: 1$. In this period all females were dealt with together, since there was no information as to which of them were, already sexually mature. The percentage of females surviving this period varied within limits of 26.8 per cent (in 1967) and 31.2 per cent (in 1968).

2. The period from the first capture to the last trapping programme in the year of birth of the females. Survival - measured by the percentage of females surviving 45 days - was analysed separately for sexually immature and mature females (including both pregnant and non-pregnant ones). Using the test for percentage differences $\left(\delta=\sqrt{\frac{p_{1}\left(1-p_{1}\right)}{n_{1}}+\frac{p_{2}\left(1-p_{2}\right)}{n_{2}}}\right.$, where $p_{1}$ and $p_{2}$ are the shares and $n_{1}$ and $n_{2}$ the numbers; when $\delta>3$, the differences are statistically significant), statistically significant differences in survival were found between these two categories of females; the survival of sexually immature females was much higher than that of mature females (on the average 72.3 per cent of the former and 58.6 per cent of the latter survived). The proportion of survivors varied between 50 per cent in 1968 and 65.4 per cent in 1967 for mature females and between 50 per cent in 1967 and 76.9 per cent in 1968 for immature females.

3. The winter period, i.e. the period from the last day of the last trapping programme in a given year to the first census in the next year. The survival of females that had not attained sexual maturity in the year of birth and that of females that had matured and entered into the state of winter anoestrus were compared. No significant differences in survival were observed between these two groups (Fig. 2; cf. Bujalska \& Gliwicz, 1972).

4. The period between the first and the last census of the next year. The proportions of survivors varied between 51.2 per cent in 1969 and 58.3 per cent in 1968 . 
The shape of the survival curves shows that the surival of females in the age group from birth to the first capture ( 37.1 per cent) and that of sexually mature females in the breeding season (58.6 per cent in the first breeding season and 54.1 per cent in the second, the difference between these two categories being statistically non-significant) were the lowest. After the breeding season the survival of mature females

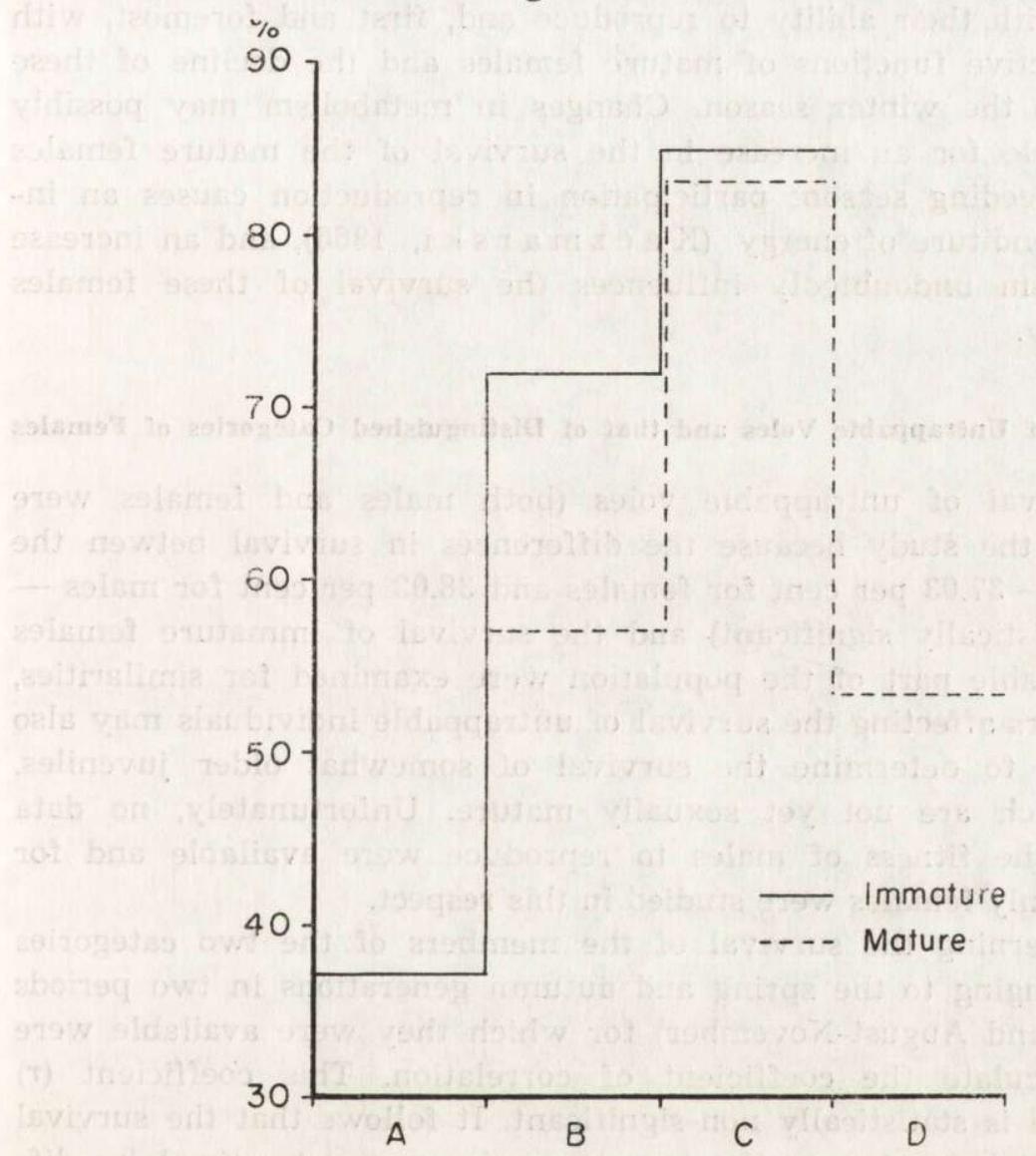

Fig. 2. Survival of females in different periods of life relative to their fitness for reproduction (percentage of survivors after a lapse of time equal to 45 days).

$A$ - from birth until first capture, $B-$ from first capture until October (first breeding season), $C$ - winter anoestrus, $D-$ second breeding season.

increased, reaching the level of survival of immature females (85.0 per cent for immature an 83.2 per cent for mature females, the difference being statistically non-significant).

The differences in survival between mature and immature females in the breeding season are independent of the age of voles in either category, since at the first capture they are all of the same age (44 days). 
This is not the case at the beginning of the winter season, when the immature females belonging to the younger cohorts are on the average 105 days old and the mature ones 142 days old, but this notwithstanding the survival rates are similar in these two categories of females. The survival of mature females and that of immature ones, being different in the breeding season and similar in winter, seem therefore to be connected with their ability to reproduce and, first and foremost, with the reproductive functions of mature females and the decline of these functions in the winter season. Changes in metabolism may possibly be responsible for an increase in the survival of the mature females after the breeding season; participation in reproduction causes an increased expenditure of energy ( $\mathrm{K} \mathrm{a} \mathrm{c} \mathrm{z} \mathrm{mar} \mathrm{s} \mathrm{ki,} \mathrm{1966),} \mathrm{and} \mathrm{an} \mathrm{increase}$ in metabolism undoubtedly influences the survival of these females unfavourably.

\subsection{Survival of Untrappable Voles and that of Distinguished Categories of Females}

The survival of untrappable voles (both males and females were included in the study because the differences in survival betwen the sex groups - 37.03 per cent for females and 38.03 per cent for males are not statistically significant) and the survival of immature females in the trappable part of the population were examined for similarities, for the factors affecting the survival of untrappable individuals may also be expected to determine the survival of somewhat older juveniles, animals which are not yet sexually mature. Unfortunately, no data concerning the fitness of males to reproduce were available and for this reason only females were studied in this respect.

Data concerning the survival of the members of the two categories studied belonging to the spring and autumn generations in two periods (April-July and August-November) for which they were available were used to calculate the coefficient of correlation. This coefficient $(r)$ is +0.064 and is statistically non-significant. It follows that the survival of individuals belonging to the two categories was determined by different factors.

Next, the survival of untrappable animals was compared with that of mature but not pregnant females (females which were not pregnant at the time of captures preceeding the birth of the cohort belonging to a given generation and which lived until the subsequent series, irrespective of whether or not they were pregnant on the latter occasion) to find if they were correlated. No significant correlation $(r=-0.0103)$ was found here either.

A third variant was therefore examined, namely, the relationship 
between the survival of untrappable individuals and that of their mothers or the females in which pregnancy had been found at the census directly preceeding the birth of the cohorts that made up the given generation. In this case the correlation was found to be significant $(r=+0.765)$ at a confidence level of $0.05<p<0.01$. Thus, there is a relationship betwen these two categories of voles as regards their survival. Moreover, here we may expect the existence of a causal nexus between the mortality of mothers and that of their progeny. Since the formula given in Section 2 for the number of individuals born, based on the mean value of $\bar{N}_{p}$, as a rule eliminates from calculation those pregnant females that died before giving birth to their progeny, it should be supposed that the correlation between these two categories of voles with respect to survival exists throughout the period from the birth of the young until they leave the nest, and thus the period when they are entirely dependent on their mothers. It is only under such conditions that the results obtained seem logical. On the basis of the foregoing consideration it may be assumed that the nesting period is particularly important to the survival of untrappable voles. This is also indicated to a certain degree by the lack of a relationship between the survival of untrappable individuals and that of immature females. It seems that here we may probably speak of the survival of the young in the nest instead of the survival of untrappable individuals. $\mathrm{R} \mathrm{a} \mathrm{j} \mathrm{s} \mathrm{k} \mathrm{a} \mathrm{(personal} \mathrm{communication),}$ studying the same population of $C$. glareolus, came to similar conclusions on a different way.

The influence of the survival of the young in the nest on the size of a population of small rodents is emphasized, among other authors, by $\mathrm{Krebs}$ et al. (1969) and W a l kow a (1971).

\subsection{Survival of Pregnant Females and their Age, Trappability and Spatial} Distribution

In searching for the reasons for the changes in the survival of pregnant females (or rather, as can be seen from the considerations in Section 4.2., nursing females) an examination was made to find if the varying survival of females was not simply a function of their age. It may be expected that the females of cohort $K_{0}$, which play the main role in reproduction from April until July, die proportionally to age, in other words, if the animals that have overwintered are, for the most part, members of the last year's spring generation, their mortality will be dependent on physiological age, but if they belong to the autumn generation, their chances for survival are better. The age of those pregnant females which died and which were born in the previous year, (from which is obtained the number of juveniles lost due to death of their mothers), 
was therefore checked. It appeared that in 1967 and 1969, the bulk of the pregnant females that died were recruited from the females of the spring generation of the previous year (33.3 and 34.5 per cent, respectively, against 6.3 and 1.7 per cent in the case of the dead females of the autumn generation). In 1968, however, the percentage of the dead females of the spring generation of the previous year was barely 12.3 per cent as against 14.8 per cent for those of the autumn generation.

Hence it follows that in years with the dynamics of the population size more levelled it was chiefly the pregnant females of the last year's spring generation that died. A decrease in their death-rate in 1968 indicates that in 1967 and 1969 the mortality was not conditioned by, "automatically" occurring physiological death and suggest that there may have been a population pressure, which in 1967 and 1969 affected mostly old females.

Pregnant females were therefore checked for the existence of a relationship between their trappability and survival, for it is probable that they as well as nursing females are more active in penetrating their home areas in search of food to make up for increased energetic losses connected with pregnancy and lactation. Increased activity - reflected to a certain extent by trappability - may result in the exposure of voles to danger from predatory animals, thus reducing the survival rate of active individuals.

Trappability, expressed by the reciprocal on the mean interval between captures $(1 / \bar{\tau}$ - see Grüm, 1959 and $\mathrm{Bujalska}, 1970)$, was determined for pregnant females in the trapping programme $t_{0}$ and their survival rate in the period dividing the trapping programme $t_{0}$ and $t$. The spring and autumn generations of all the years of study were compared. The coefficient of correlation $(r)$, equal to +0.297 , is not statistically significant, which proves that the cause of death of females in the period of study was not connected with the action of a non-specialized predator.

The question arises whether the changes in the survival rate are accompanied by changes in the spatial distribution of the population and, say, by a resultant increase in the overlapping of home ranges and, a resultant increase, in the frequency of meetings between voles, which may lead to disturbances in the balance in the pituitary-adrenal system and to death (Christian, 1971; T an a ka, 1953). Spatial distribution was determined using Lloy ds (1967) formula $\hat{x} / \bar{x}$

where $\hat{x}=\frac{\sum_{j=1}^{q} X_{j}^{2}}{\sum_{j=1}^{q} X_{j}}-1 \quad$ and $\bar{x}=\frac{\sum_{j=1}^{q} X_{j}}{q}$, 
$x_{j}$ is the number of specimens in sample $j$, and $q$ the number of samples. When $\hat{x} / \bar{x}<1$, the distribution is uniform, whereas $\hat{x} / \bar{x}=1$ denotes random distribution and $\hat{x} / \bar{x}>1$ clumped one. The standard error of $\hat{\bar{x}}$ was assessed by the formula:

$$
\text { S. E. }\left[\frac{\hat{x}}{\bar{x}}\right]=\frac{S^{2}}{\bar{x}^{2}} \sqrt{\frac{\overline{2} \bar{x}}{q \hat{x}}}
$$

Comparison was carried out in the same way as in the analysis of relationship between trappability and survival. The coefficient of correlation $(r)$ is +0.243 and statistically non-significant. If the causes of changes in the survival of pregnant (nursing) females lie in the relationship between individuals (and consequently depend on relations within the population), they are not controlled by changes in spatial distribution.

\section{DISCUSSION}

The finding out of the fact that the survival of the untrappable members of a population is conditioned by the survival of their mothers, reduces these considerations to the sphere of problems associated with the influence of population density on these course of main population processes, such as reproduction and mortality.

It has been demonstrated $(\mathrm{Bujalska}, 1970)$ that in the population of C. glareolus under study, reproduction, although inversely proportional to density, was not dependent on it in the sense of cause and effect. The relationship between survival and population density should therefore be considered. If it is admitted that the decrease in the population size in the second part of the breeding season was caused by a drop in the survival of mothers and their dependent progeny, and if, in addition the influence of the higher survival of mothers on the occurrence of a peak in the population size is taken into account, the direct influence of population density seems obscure, for the survival of females with progeny was higher in the years with a peak, although the initial population density was constant and, what is more, the population size in the period directly preceeding the occurrence of the peak (June) was higher than it was in the other years. In addition, the decrease in the survival of the above-mentioned category of females in the second part of the breeding season was not compatible with the population density. Thus, for instance, the mean longevity of the autumn generation in 1966 was 34 days, the mean population size at the time of birth of this generation 
being 283 individuals and in 1968 it was 53 days at the mean population size of 394 individuals. It therefore seems that one cannot speak of the direct dependence of survival on density either. It may be supposed that the changes in the survival rate of mothers were a function of another factor, which, consequently, is only indirectly responsible for the size of population. This factor must be one of the exhaustible elements. It may well be that it is food.

The varying death-rate and reproduction of females at the time of the peak in the size of population are noteworthy. In 1966 the survival rate of females was lowered to about one-quarter of that observed before the peak and it approximated to the survival rate of males. The number of sexually mature females kept at the same level. On the other hand, in 1968 the survival rate of females was reduced only by half and it largely exceeded the value obtained for males. At the same time, there was a fall in the number of sexually mature females and anoestrus was observed in some of the females that had bred before $(\mathrm{B} \mathrm{u} \mathrm{jalska}$, 1970). This phenomenon may suggest that reproduction and mortality are two complementary factors contributing to the reduction of the population size. The high mortality of females in 1966 (mean longevity of females of autumn generation - 35 days, that of males -33 days) did not bring about a decrease in potential natality (expressed by the number of sexually mature females), whereas in 1968, when the mortality rate was lower (mean longevity of females of autumn generation - 61 days, that of males - 45 days), an additional mechanism, i.e. the fall in reproduction - began to act, leading to a decrease in the size of the population. In the light of the present results it is mortality that seems to reduce the population size most dramatically. As regards 1968, we may speak of sex specific factors ( $\mathrm{K} \mathrm{re} \mathrm{bs}$ et al., 1969), which, differentiating the survival rates of the sexes, caused a decrease in the reproductive potential. According to the results of the present work, the fall in the survival rate of females is due chiefly to the fall in the survival rate of sexually mature females (in the breeding season they live a considerably shorter time than do immature females) and, in consequence, to their offspring. Special attention should be given to overwintered voles of the spring generation, whose mortality is more variable than that of the autumn generation. This indicates their greater "susceptibility " and thus draws attention to different roles played by the two generations in the regulation of the size of population.

Acknowledgements: I wish to express my thanks to Prof. Zdzisław $\mathrm{P}$ u ce $\mathrm{k}$, Head of the Mammals Research Institute at Bialowieża, for critical remarks which helped me to prepare this work for publication. Mr T. D. H e a ling (Royal Holloway College, University of London) kindly helped me with the translatation. 


\section{REFERENCES}

1. Bergstedt B., 1965: Distribution, reproduction, growth and dynamics of the rodent species Clethrionomys glareolus ( $\mathrm{S} \mathrm{chreber}$ ), Apodemus flavicollis ( $\mathrm{Mel} \mathrm{chior}$ ) and Apodemus sylvaticus ( $\mathrm{L}$ inné) in southern Sweden. Oikos, 16: 132-160.

2. Bujalska, G., 1967: Estimation of reproduction in Clethrionomys glareolus (S c h r e ber, 1780). Small Mammal Newslett., 3: 27-28.

3. Bujalska G., 1970: Reproduction stabilizing elements in an island population of Clethrionomys glareolus (S ch re be r, 1780). Acta theriol., 15: 381-412 .

4. Bujalska G., 1973: The rôle of spacing behaviour among females in the regulation of reproduction in the bank vole. J. Reprod. Fert., Suppl., 19: 463$-472$.

5. Bujalska.G., Andrzejewski R. \& Petrusewicz K., 1968: Productivity investigations of an island population of Clethrionomys glareolus (Sc h r e ber, 1780). II. Natality. Acta theriol., 13: 415-425.

6. Bujalska G. \& Gliwicz J., 1972: Growth and reproduction of female bank voles under field conditions. Acta theriol., 17: 33-40.

7. Bujalska G. \& Ryszkowski L., 1966: Estimation of the reproduction of the bank voles under field conditions. Acta theriol., 11: 351-361.

8. Christian J. J., 1961: Phenomena associated with population density. Proc. Nat. Acad. Sci., 47: 428-449.

9. Christian J. J., 1971: Population density and reproductive efficiency. Biol. Reprod., 4: 248-294.

10. Gliwicz J., Andrzejewski R., Bujalska G. \& Petruse wicz K., 1968: Productivity investigations of an island populations of Clethrionomys glareolus (S chreber, 1780). I. Dynamics of cohorts. Acta theriol. 13: 401-413.

11. Grüm L., 1959: Sezonowe zmiany aktywności biegaczowatych (Carabidae) [Seasonal changes of activity of the Carabidae]. Ekol. pol., A, 7: 255-268.

12. Ka c z marski F., 1966: Bioenergetics of pregnancy and lactation in the vole, Acta theriol., 11: 409-417.

13. Kalela O., 1957: Regulation of reproduction rate in subarctic populations of the vole Clethrionomys rufocanus (Sund.). Annls Acad. Sci. Fennicae, A, 4: $7-60$.

14. $\mathrm{Krebs}$ C. J., 1970: Microtus population biology: behavioral changes associated with the population cycle in $M$. ochrogaster and $M$. pennsylvanicus. Ecology, 51: $34-52$.

15. Krebs C. J., Keller B. L. \& Tamarin R. H., 1969: Microtus population biology: demographic changes in fluctuating populations of $M$. ochrogaster and $M$. pennsylvanicus in southern Indiana. Ecology, 50: 585-607.

16. Petrusewicz K., Bujalska G., Andrzejewski R. \& Gliwicz J., 1971: Productivity processes in an island population of Clethrionomys glareolus. Ann. Zool. Fennici 8: 127-132.

17. Tanaka R., 1953: Home ranges and territories in a Clethrionomys population on a peat-bog grassland in Hokkaido. Bull. Kochi Wom. Coll., 2: 10-20.

18. Llo y d M., 1967: Mean crowding. J. anim. Ecol., 36: 1-30.

19. Traczyk H., 1965: The vegetation of "The Wild Apple-Tree Island " on the Lake Bełdańskie (North-Eastern Poland), Fragm. flor. geobot., 11: 541-545. 
20. Walkowa W., 1971: The effect of exploitation on the productivity of laboratory mouse populations. Acta theriol., 16, 19: 295-328.

21. Z j jda J., 1966: Litter size in Clethrionomys glareolus (S chreber, 1780). Zool. Listy, 15: 193-204.

Accepted, August 9, 1974.

Institute of Ecology,

Polish Academy of Sciences,

Dziekanów Leśny, 05-150 Łomianki, Poland.

Gabriela BUJALSKA

\section{ROZRODCZOSC I SMIERTELNOSC A ZMIANY LICZEBNOSCI WYSPOWEJ} POPULACJI CLETHRIONOMYS GLAREOLUS (S C HRE B ER, 1780)

\section{Streszczenie}

Badania prowadzono w latach 1966-1969 na 4 ha wyspie na jeziorze Beldany. Informacje zbierano stosując metodę CMR w czasie serii połowów przeprowadzanych pięciokrotnie w ciągu każdego roku badań. Stan liczebności populacji okrcślano metodą „spisu powszechnego".

Stwierdzono, że przyczyną wystąpienia lipcowego szczytu liczebności w latach 1966 i 1968 była lepsza przeżywalność generacji wiosennej. Liczba urodzonych nie odegrała tu istotnej rołi.

Lepsza przeżywalność generacji wiosennej w latach szczytu liczebności znalazła swój wyraz w średniej długości życia: osobniki z generacji wiosennej urodzone w latach szczytu żyły dwukrotnie dłużej niż w latach pozostałych (Tabela 2). Szczególnie istotne znaczenie miała przeżywalność młodzieży w okresie od urodzenia do pierwszego złowienia (Ryc. 1). Ponieważ była ona skorelowana z przeźywalnością rodzących samic przypuszcza się, że dotyczyła ona młodzieży w wieku gniazdowwym.

Zaobserwowanc, że samice dojrzałe płciowo przeżywały w sezonie rozrodczym gorzej niż samice niedojrzałe plciowo (Ryc. 2). Po zakończeniu sezonu rozrodczego przeżywalność samic dojrzałych wzrastała i była podobna do przeżywalności samic niedojrzałych. Wskazuje to na istnienie zależności między funkcjami rozrodczymi a przeżywalnością.

Przedyskutowano wyniki pracy, świadczące o braku odwrotnie proporcjonalnej należności między zagęszczeniem populacji a śmiertelnością i zwrócono uwagę na stnienie kompensacyjnego działania rozrodczości i śmiertelności w procesie regulacji liczebności populacji. 